\title{
ANALISIS SISTEM REKRUITMEN DAN SELEKSI AMILIN (STUDI KASUS DI BADAN AMIL ZAKAT KOTA BOGOR DAN LEMBAGA AMIL ZAKAT DHOMPET DHUAFA)
}

\section{ANALYSIS RECRUITMENT AND SELECTION SYSTEM OF AMILIN (CASE STUDY IN BAZ BOGOR CITY AND LAZ DOMPET DHUAFA)}

\author{
M. Amanah'1a, M. Paramita ${ }^{2 b}$ \\ 1aAlumni Program Studi Ekonomi Islam Fakultas Ekonomi Islam Universitas Djuanda, Jl. Tol Ciawi \\ No. 1, Kotak Pos 35 Bogor 16770. \\ 2 Dosen Program Studi Ekonomi Islam Fakultas Ekonomi Islam Universitas Djuanda, Jl. Tol Ciawi \\ No. 1, Kotak Pos 35 Bogor 16770
}

(Diterima oleh Dewan Redaksi: Agustus)

(Dipublikasikan oleh Dewan Redaksi:Desember)

\begin{abstract}
Amilin has a very important role in efforts to optimize the zakat system as one process of redistribution of income, so that the management of zakat requires professionalism in the handling. The aim of this study was to determine the characteristics of the existing Amilin in BAZ Bogor city and LAZ Dompet Dhuafa, and recruitment mechanisms implemented in each institution to get Amilin. Data analysis method used is the importance of performance analysis (IPA )which is an application technique to measure variablesf rom interest grade to implementation. Beside IPA method, the research use Fish Diagram method, by using this method the problems will be revealed. So, it can be done amelioration. Based on analysis results about recruit and selection system of Amilin (Case Study at Badan Amil Zakat Kota Bogor and Lembaga Amil Zakat Dompet Dhuafa). It gained 0,372- 0,795 correlation value from every variable, and with cronbach'salfa 0,933 . That scored which shown above proved that all instruments are reliable and valid. And from the analysis results got that variables which have to stay under recruit and selection system at BAZ kota Bogor are Spirituality and emotionality, while at LAZ Dompet Dhuafa there are Spirituality, emotionality, and intellectuality. These results proved by variables at second quadrant in kartesius diagram.
\end{abstract}

Keywords: Recruitment, Selection, Amilin

\begin{abstract}
ABSTRAK
Peranan amilin sangat penting dalam upaya optimalisasi sistem zakat sebagai salah satu proses redistribusi income, sehingga kepengurusan dana zakat menuntut profesionalitas dalam penanganannya. Tujuan dari penelitian ini adalah untuk mengetahui karakteristik amilin yang ada pada BAZNAS Kota Bogor dan LAZ Dompet Dhuafa, dan mekanisme perekrutan yang diterapkan dimasing-masing lembaga untuk mendapatkan amilin. Metode analisis data yang digunakan adalah metode importance performance analysis (IPA) yang merupakan suatu teknik penerapan untuk mengukur variabel dari tingkat kepentingan dan kenyataan. Selain metode IPA dalam penelitian ini digunakan pula metode diagram ikan, dengan metode ini dapat diketahui akar dari penyebab terjadinya masalah sehingga dapat dilakukan langkah perbaikan. Berdasarkan hasil analisis mengenai mekanisme perekrutan maka didapat variabel yang paling menentukan dalam sistem perekrutan yaitu terdapat
\end{abstract}


dalam segi spiritual. Hal ini terbukti dengan keberadan variabel spiritual di kuadran I dalam diagram kartesius yang merupakan variabel yang memiliki prioritas utama dalam perbaikannya.

Kata Kunci: Rekruitmen, Seleksi, Amilin.

Amanah M. 2013. Analisis Sistem Rekruitmen dan Seleksi Amilin. Jurnal Syarikah (2):113 130 .

\section{PENDAHULUAN}

Pentingnya melaksanakan zakat dibuktikan dengan adanya 27 ayat dalam Al-Qur'an yang mensejajarkan kewajiban shalat dengan kewajiban zakat dalam berbagai bentuk kata, seperti yang terdapat pada Al-qur'an surat Al-Baqarah ayat 43:

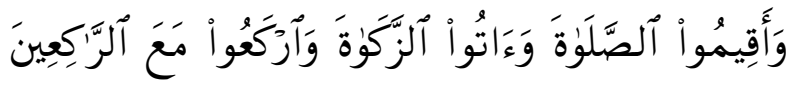

Artinya: "Dan dirikanlah shalat, tunaikanlah zakat dan ruku'lah beserta orang-orang yang ruku".

Rasulullah Muhammad SAW. adalah manusia agung yang menjadi panutan umat manusia sedunia hingga akhir zaman, termasuk dalam hal berzakat:

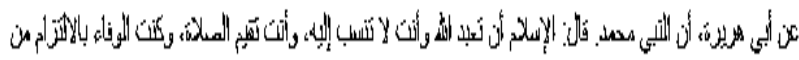

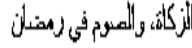

Dari Abu Hurairah, bahwa Rasulullah SAW. bersabda: Islam adalah engkau beribadah kepada Allah dan janganlah mempersekutukan-Nya, dan engkau menegakkan shalat, dan engkau menunaikan kewajiban zakat, dan berpuasa di bulan Ramadhan.

Dari Ibnu Umar bin al-khattab ra. sesungguhnya Rasulullah SAW. bersabda: "Aku perintahkan untuk memerangi manusia hingga mereka bersaksi bahwa tiada Tuhan selain Allah dan Muhammad adalah Rasulullah, menegakkan shalat, menunaikan zakat. Jika mereka melakukan hal itu, maka darah dan harta mereka akan dilindungi kecuali atas hak Islam, dan perhitungan mereka ada pada Allah SWT. (HR.Bukhari dan Muslim)
Peranan zakat sebagai indikasi seorang muslim, harus menjadi perhatian banyak kalangan dalam masalah pelaksanaannya, terutama lembagalembaga keuangan dan pihak pemerintah. Zakat dengan infak dan sedekahnya adalah sumber dana yang sangat potensial. Zakat dapat menjadi instrumen yang amat penting dalam pemberdayaan ekonomi umat, pengentasan kemiskinan dan dapat pula mengurangi kesenjangan sosial.

Dalam sejarah kejayaan Islam, zakat terbukti berperan besar dalam meningkatkan kesejahteraan umat. Tidak sekedar kewajiban, tapi lebih dari itu zakat dikelola dengan baik dan didistribusikan secara adil kepada orang-orang yang berhak. Dikisahkan pada zaman Abu Bakar As-sidiq ra. Ketika beliau bersikukuh untuk memerangi kaum yang murtad karena memisahkan antara shalat dengan zakat.

Sebagai contoh bahwa cukup dengan dana zakat semua masyarakat dapat hidup dengan sejahtera adalah apa yang berlaku di Yaman, yang merupakan salah satu daerah kekuasaaan Khalifah Umar bin Khathab. Saat itu kesejahteraan umat tersebar merata, sehingga secara ekonomi tidak ada warga yang berhak menerima zakat. Begitupun pada masa setelahnya, yaitu pada periode daulah Bani Umayah. Salah satu Khalifahnya, Umar bin Abdul Aziz, dalam waktu singkat yaitu sekitar dua tahun (99-101 H), berhasil mensejahterakan masyarakat dengan dana zakat, infak, dan sedekah. Bahkan di baitul maal dana zakat berlimpah. Hal ini sangat menyulitkan petugas amil zakat pada masa itu, karena mereka kesulitan menemukan warga yang tergolong fakir dan miskin.

Sekilas mengenai sejarah di atas merupakan bukti bahwa setiap ketetapan 
yang Allah SWT turunkan mengandung kebaikan bagi umat manusia. Mengenai zakat dan penerapannya bila dilakukan dengan sungguh-sungguh akan mampu menghasilkan kondisi perekonomian umat yang baik. Kesadaran masyarakat dalam menunaikan kewajiban zakat, profesionalitas pengelolanya, dan kapabilitas amil zakat adalah beberapa faktor penunjang yang berperan dalam penerapan zakat guna mewujudkan kesejahteraan dan kemakmuran masyarakat.

Dalam upaya optimalisasi sistem zakat sebagai salah satu proses redistribusi income, posisi amil dalam kelompok delapan asnaf memiliki peranan yang luar biasa. Terdapatnya amil zakat di dalam delapan asnaf dan menerima harta zakat menunjukkan bahwa zakat adalah urusan yang sangat penting dalam Islam sehingga pengurusannya tidak bisa diserahkan kepada individu-individu, tetapi harus diserahkan kepada sebuah institusi dibawah negara, dan hal ini tentu saja akan menuntut profesionalitas dalam penanganannya.

Kontribusi sumber daya manusia dalam hal ini amilin dinilai sangat signifikan dalam pencapaian tujuan organisasi. Untuk mencapai tujuan tersebut segala upaya harus dilakukan untuk menentukan sebuah sistem yang dapat mengatur kinerja amilin agar lebih efektif dan efisien dalam organisasi, maka rekruitmen dan seleksi terhadap para amilin yang potensial dan bermotivasi tinggi untuk mengembangkan sumber daya manusia menjadi pilihan strategis yang harus dilakukan pengelola zakat.

Rekruitmen dan seleksi termasuk fungsi-fungsi manajemen sumber daya manusia yang mempunyai peran strategis dalam mempersiapkan dan menyediakan sumber daya manusia termasuk amilin yang sesuai dengan kebutuhan pekerjaan, sebagaimana ditetapkan dalam analisis pekerjaan khususnya deskripsi dan spesifikasi. Kedua kegiatan tersebut didahului oleh kegiatan analisis pekerjaan dan perencanaan sumber daya manusia. Hal ini berarti bahwa kegiatan rekruitmen dan seleksi harus didasarkan pada suatu kebutuhan yang dialami oleh organisasi, baik dalam segi fisik maupun dari segi kemampuan dan keterampilan. Pelaksanaan kedua kegiatan tersebut jika secara wajar dikerjakan sesuai dengan prinsip-prinsip manajemen yang baik, niscaya dapat mencegah suatu organisasi dalam masalah surplus pegawai kecuali karena adanya faktor-faktor eksternal yang tidak dapat dikendalikan oleh organisasi itu sendiri.

Produktivitas dan kinerja yang tinggi akan lebih terjamin jika organisasi mempunyai cara yang tepat untuk menjaga keprofesionalan amilin. Melalui pemeriksaan psikologis dalam rekruitmen dan seleksi, organisasi akan memperoleh amilin potensial yang sesuai tuntutan pekerjaan. Demikian pula halnya untuk evaluasi potensi dan promosi amilin, dapat dilakukan pemeriksaan psikologis yang berkaitan dengan prestasi kerja sehingga manajemen dapat mengambil keputusan dan penanganan yang tepat dalam mengembangkan SDM organisasi.

Tidak bisa dipungkiri lagi bila profesionalisme amilin berkorelasi dengan perolehan jumlah penghimpunan (donasi) seperti yang sekarang terjadi. Ada lembaga amilin yang pendapatannya begitu tinggi, ada yang sedang, tak sedikit pula yang rendah. Mereka yang mampu mendapatkan dana tinggi karena ditopang oleh SDM yang berkualitas dan di back up sistem modern. Dan yang tak kalah penting mereka mampu menjaga kepercayaan (amanah) masyarakat melalui transparansi karena itu sudah menjadi keniscayaan dari akuntabilitas lembaga yang mengelola dana publik. Dengan demikian tanpa diminta atau diperintah kesadaran masyarakat untuk mengeluarkan zakat pada lembaga tersebut dengan sendirinya berjalan.

Mengingat sangat pentingnya proses rekruitmen dan seleksi bagi perusahaan. Diharapkan dengan adanya proses rekruitmen dan seleksi yang baik dan 
efektif akan berdampak pada perkembangan LPZ kedepannya untuk memperoleh sumber daya yang berkualitas.

\section{MATERI DAN METODE}

Jenis penelitian yang digunakan dalam menganalisis sistem rekruitmen ini merupakan penelitian deskriptif kualitatif , dengan jenis penelitian studi kasus yaitu bertujuan untuk menggambarkan tentang fenomena yang ada, sifat sesuatu yang tengah berlangsung pada saat penelitian dilakukan. Adapun responden yang akan diambil dalam penelitian ini adalah para amilin.

Pada penelitian ini, penulis menjadikan amilin dari Badan Amil Zakat Kota Bogor dan Dompet Dhuafa sebagai populasi. Menurut hasil wawancara pada tahun 2013 ini jumlah amilin yang ada pada BAZ Kota Bogor itu berjumlah 25 orang dan jumlah amilin yang ada pada LAZ Dompet Dhuafa yaitu sebanyak yang 34 orang. Kemudian akan digunakan metode Simple Random Sampling, yaitu metode penarikan sampel dimana setiap anggota populasi mempunyai peluang yang sama untuk dipilih menjadi sampel.

Untuk menentukan besarnya jumlah sample yang akan digunakan dalam Penelitian ini adalah dengan menggunakan rumus Slovin. Adapun rumus Slovin sebagai berikut :

$$
n=\frac{N}{1+N(e)^{2}}
$$

Dimana :

$\mathrm{n}=$ Jumlah sampel yang diambil

$\mathrm{N}=$ Jumlah populasi

$\mathrm{e}=$ Batas ketelitian (margin error), ditetapkan sebesar $10 \%$

Berdasarkan rumus tersebut, maka jumlah sampel yang diambil dalam penelitian yaitu:

Untuk sampel pada BAZ Kota Bogor adalah sebagai berikut:

$$
n=\frac{25}{1+25(0.1)^{2}}=\frac{25}{1.25}=20
$$

Sedangkan untuk jumlah sampel pada LAZ Dompet Dhuafa adalah sebagai berikut:

$$
n=\frac{45}{1+45(0.1)^{2}}=\frac{45}{1.45}=31
$$

Berdasarkan hasil perhitungan di atas maka telah ditentukan banyaknya sampel yang dapat diambil dari tiap-tiap lembaga yaitu sebanyak 20 orang amilin untuk BAZ Kota Bogor dan 31 orang untuk LAZ Dompet Dhuafa.

Objek penelitian adalah para Amilin dengan fokus penelitian yaitu tentang Analisis Sistem Rekruitmen dan Seleksi Amilin (studi kasus BAZ Kota Bogor dan LAZ Dompet Dhuafa).

Teknik pengumpulan data dalam penelitian ini adalah dengan menggunakan Teknik wawancara, yaitu melakukan proses Tanya jawab atau interview secara langsung terhadap sasaran yang dijadikan objek penelitian untuk memperoleh informasi yang tepat dan akurat sesuai dengan kondisi yang terjadi sebenarnya. Dan penyebaran kuisioner dengan penilaian menggunakan skala likert.

Metode yang digunakan dalam penelitian ini untuk mengetahui tingkat Importance dan performance dari variablevariabel rekruitmen dan seleksi yang ada pada lembaga yaitu metode Importance Performance Analysis (IPA) dan metode diagram ikan.

Diagram tulang ikan atau fishbone diagram adalah salah satu metode/tool di dalam meningkatkan kualitas. Penerapan diagram Fishbone (Tulang Ikan)/Cause and Effect (Sebab dan Akibat)/Ishikawa ini dapat menolong kita untuk dapat menemukan akar "penyebab" terjadinya masalah khususnya di industri manufaktur dimana prosesnya terkenal dengan banyaknya ragam variabel yang berpotensi menyebabkan munculnya permasalahan. Apabila "masalah" dan "penyebab" sudah diketahui secara pasti, maka tindakan dan langkah perbaikan akan lebih mudah dilakukan. Dengan diagram ini, semuanya menjadi lebih jelas dan memungkinkan kita untuk dapat melihat semua kemungkinan 
"penyebab" dan mencari "akar" permasalahan sebenarnya.

Metode IPA merupakan suatu teknik penerapan untuk mengukur atribut dari tingkat kepentingan dan pelaksanaan. Sumbu mendatar (X) diisi skor rataan tingkat kinerja aktual, dan sumbu tegak (Y) diisi skor rataan tingkat kepentingan atribut. Masing-masing dihitung dengan rumus seperti di bawah ini:

$$
\begin{aligned}
& \bar{X}=\frac{X i}{n} \\
& \bar{Y}=\frac{\sum Y i}{n}
\end{aligned}
$$

Dimana :

$$
\begin{aligned}
& \bar{X}=\text { skor rata-rata tingkat kepuasan } \\
& \bar{Y}=\text { skor rata-rata tingkat } \\
& \text { kepentingan } \\
& \mathrm{n}=\text { jumlah responden } \\
& \text { Diagram dibagi menjadi empat }
\end{aligned}
$$
bagian yang dibatasi oleh dua garis yang berpotongan tegak lurus dengan titik-titik $(X, Y)$, titik tersebut diperoleh dari rumus:

$$
\begin{gathered}
x=\frac{\sum x i}{k} \\
y=\frac{\sum y i}{k}
\end{gathered}
$$

Dimana:

$X=$ Rata-rata dari skor rata-rata tingkat kinerja dari keseluruhan faktor kinerja

$Y=$ Rata-rata dari skor rata-rata tingkat kepentingan pada setiap atribut.

$\mathrm{K}=$ Banyaknya atribut yang mempengaruhi kepuasan. Tingkat unsur-unsur tersebut selanjutnya akan dijabarkan dan dibagi menjadi empat bagian ke dalam diagram kartesius seperti pada Gambar 1 dibawah ini:

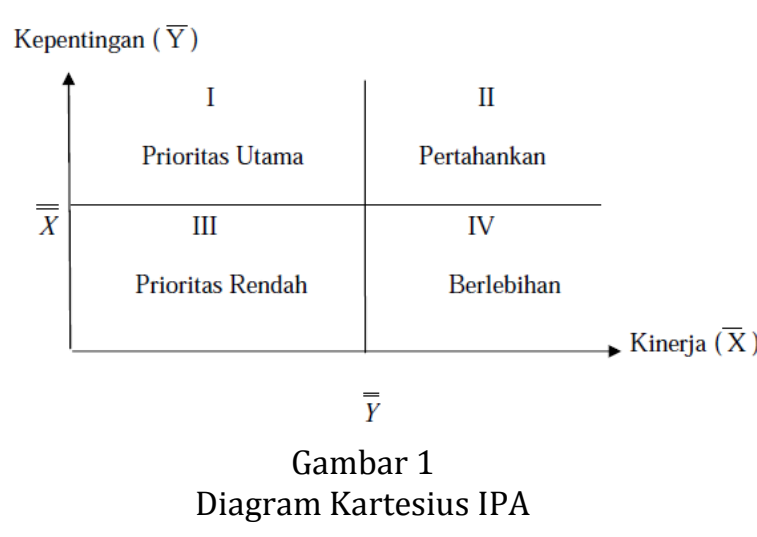

Penelitian ini dilakukan pada dua Lembaga Zakat yaitu Badan Amil Zakat Kota Bogor dan Dompet Dhuafa, dengan pertimbangan bahwa masing-masing Lembaga merupakan sebuah Lembaga Zakat yang telah dikenal oleh masyarakat sehingga tidak diragukan lagi akan kinerjanya dibidang pengelolaan zakat.

\section{HASIL DAN PEMBAHASAN}

\section{Karakteristik Responden}

Karakteristik responden menguraikan atau menggambarkan indentitas responden yang dijadikan sebagai sampel penelitian. Dalam pembahasan profil responden ditetapkan masing-masing 20 responden dari tiap lembaga amil zakat. Dimana penyebaran kuisioner ini diberikan kepada responden yang telah mengembalikan kuisioner dan telah diisi secara lengkap dan benar, kemudian perlu diketahu bahwa dalam karakteristik responden ini yang ditekankan adalah berdasarkan jenis kelamin, tingkat pendidikan terakhir dan berdasarkan lama kerja. Hal ini dapat diuraikan melalui pembahasan berikut ini:

Karakter responden berdasarkan jenis kelamin yaitu menguraikan atau menggambarkan jenis kelamin responden. Hal ini dapat dikelompokkan menjadi 2 kelompok yaitu : laki-laki dan perempuan. Adapun karakteristik responden menurut jenis kelamin telah disajikan melalui tabel berikut ini: 
Tabel 1. Karakteristik responden berdasarkan Jenis Kelamin di Lembaga Zakat Dompet Dhuafa

\begin{tabular}{cccc}
\hline No & $\begin{array}{c}\text { Jenis } \\
\text { Kelamin }\end{array}$ & $\begin{array}{c}\text { Frekuensi } \\
\text { (orang) }\end{array}$ & $\begin{array}{c}\text { Persentase } \\
\%\end{array}$ \\
\hline 1. & Laki-laki & 12 & 38,7 \\
2. & Perempuan & 19 & 61,29 \\
& Jumlah & 31 & 100 \\
& responden & & \\
\hline
\end{tabular}

Sumber: data diolah

Berdasarkan tabel di atas deskripsi profil responden menurut jenis kelamin (gender) pada LAZ Dompet Dhuafa menunjukkan bahwa mayoritas responden lebih banyak didominasi oleh perempuan jika dibandingkan dengan laki-laki.

Sedangkan keadaan karakteristik responden berdasarkan jenis kelamin pada Badan Amil Zakat Kota Bogor dapat dilihat pada tabel di berikut ini:

Tabel 2. Karakteristik Responden Berdasarkan Jenis Kelamin di Badan Amil Zakat Kota Bogor

\begin{tabular}{cccc}
\hline No & $\begin{array}{c}\text { Jenis } \\
\text { Kelamin }\end{array}$ & $\begin{array}{c}\text { Frekuensi } \\
\text { (orang) }\end{array}$ & $\begin{array}{c}\text { Persentase } \\
\%\end{array}$ \\
\hline 1. & Laki-laki & 11 & 55 \\
2. & $\begin{array}{c}\text { Perempuan } \\
\text { Jumlah }\end{array}$ & 9 & 45 \\
& responden & 20 & 100 \\
\hline
\end{tabular}

Sumber: data diolah

Terdapat dua teori peran laki-laki dan perempuan yang berlawanan, yaitu teori nature dan teori nurture. Teori nature yang disokong oleh teori biologis dan teori fungsionalisme struktural ini, mengatakan bahwa perbedaan peran gender bersumber dari perbedaan biologis laki-laki dan perempuan. Sedangkan teori nurture, yang disokong oleh teori konflik dan teori feminisme, mengandaikan bahwa perbedaan peran gender antara laki-laki dan perempuan bukan merupakan konsekuensi dari perbedaan biologis yang kodrati, namun lebih sebagai hasil konstruksi manusia, yang pembentukannya sangat dipengaruhi oleh kondisi sosiokultural yang melingkupinya.

Dalam banyak hal, berdasarkan pada pertimbangan-pertimbangan tertentu, banyak perusahaan yang memilih mempekerjakan perempuan dibanding laki-laki seperti yang terjadi pada Lembaga Amil Zakat Dompet Dhuafa, sedangkan pada BAZ Kota Bogor mensejajarkan posisi antara perempuan dan laki-laki dalam memperoleh kedudukan menjadi seorang amilin. Dalam Islam perempuan ditempatkan pada posisi yang tinggi dan sejajar dengan laki-laki. Namun dalam beberapa hal ada yang harus berbeda, karena laki-laki dan perempuan hakikatnya adalah makhluk yang berbeda. Perbedaan ini dikarenakan adanya perbedaan struktur otak antara pria dan wanita. Perbedaan struktur otak ini mengakibatkan perbedaan pula pada cara memproses informasi yang masuk kedalam otak dan mengakibatkan perbedaan pada prioritas, tingkah laku, persepsi dan pengertian pada laki-laki dan perempuan.

Dari jangkauan sudut pandang, jika diukur dari hidung, maka wanita mempunyai jangkauan sudut pandang yang relatif lebih besar. Jangkauan sudut pandang wanita berkisar antara 45 derajat sampai dengan 180 derajat, diukur dari hidung kearah kanan kiri atas bawah. Jadi kaum wanita, dengan jangkauan sudut pandang yang luas itu bisa melihat isi lemari tanpa menggerakkan kepalanya, hanya dengan melirik saja mereka bisa menemukan barang yang dicari. Ini berbeda dengan kaum pria yang mempunyai sudut pandang yang relatif lebih kecil. Laki-laki jika memandang sesuatu maka otak akan memproses pandangannya itu jauh dan lebih fokus, dan juga akan mencari "kata" yang tertulis diotak tentang benda yang dicari atau ingin dilihat.

Dalam struktur otak wanita, kemampuan untuk berbicara terutama ada dibagian depan otak kiri dan sebagian kecil 
di otak sebelah kanan. Sementara untuk pria, kemampuan berbicara dan bahasa itu bukan kemampuan otak yang penting. Otak pria itu terkotak-kotak dan mampu memilah-milah informasi yang masuk dan berkembang sedemikian rupa sehingga mereka hanya dapat berkonsentrasi pada satu hal yang spesifik pada suatu saat, karena sedikit sekali jaringan yang menghubungkan otak kiri dan kanan pria.Sementara pada otak wanita punya konstruksi yang memungkinkan wanita melakukan banyak hal sekaligus multitasking job, dan otaknya tidak pernah putus, selalu aktif.

Dalam berbicara, biasanya perempuan menggunakan indirect speech atau memberikan isyarat tentang apa yang sebenarnya dia inginkan. Tujuannya adalah untuk menghindari konflik atau konfrontasi sehingga bisa terjalin hubungan yang harmonis satu sama lain. Indirect speech biasanya menggunakan kata-kata seperti: 'kayaknya', 'sepertinya' dan sebagainya. Ketika perempuan bicara menggunakan indirect speech kepada perempuan lain, tidak pernah ada masalah, karena perempuan lain cukup sensitif untuk mengerti maksud sebenarnya, akan tetapi akan berbeda bila dipakai untuk bicara dengan laki-laki, karena laki-laki tidak sesensitif perempuan. Oleh karenanya sudah sewajarnya jika lebih banyak perempuan yang berada dalam bidang ini.

Karakter responden menurut jenjang pendidikan adalah menguraikan atau menggambarkan responden menurut jenjang pendidikan terakhir. Oleh karena itulah akan disajikan deskripsi profil responden berdasarkan jenjang pendidikan terakhir yang dapat dilihat melalui tabel berikut ini:

Tabel 3. Karakteristik Responden Berdasarkan Jenjang pendidikan pada Dompet Dhuafa

\begin{tabular}{cccc}
\hline No & Jenjang \\
Pendidikan & $\begin{array}{c}\text { Frekuensi } \\
\text { (Orang) }\end{array}$ & $\begin{array}{c}\text { Persentase } \\
(\%)\end{array}$ \\
\hline
\end{tabular}

\begin{tabular}{lccc}
\hline 1 & SMA & 2 & 6,45 \\
2 & Diploma & 4 & 12,9 \\
3 & Sarjana & 24 & 77,42 \\
& (S1) & & \\
4 & Pasca & 1 & 3,23 \\
& Sarjana & & \\
& (S2) & & \\
& Total & 31 & 100 \\
\hline
\end{tabular}

Sumber: data diolah

Tabel berikut ini yaitu tabel deskripsi profil responden menurut jenjang pendidikan terakhir, ternyata responden lebih banyak memiliki jenjang pendidikan S1 pada Dompet Dhuafa dan jenjang pendidikan SMA pada BAZ Kota Bogor.

\begin{tabular}{|c|c|c|c|c|}
\hline Tabel & 4. & $\begin{array}{l}\text { Kar } \\
\text { Ber } \\
\text { pen }\end{array}$ & $\begin{array}{l}\text { kteristik } \\
\text { asarkan } \\
\text { lidikan BAZ }\end{array}$ & $\begin{array}{c}\text { Responden } \\
\text { Jenjang } \\
\text { Kota Bogor }\end{array}$ \\
\hline No & $\begin{array}{r}\text { Jenj } \\
\text { Pendic }\end{array}$ & $\begin{array}{l}\text { ng } \\
\text { ikan }\end{array}$ & $\begin{array}{c}\text { Frekuensi } \\
\text { (Orang) }\end{array}$ & $\begin{array}{c}\text { Persentase } \\
(\%)\end{array}$ \\
\hline 1 & $\mathrm{SM}$ & & 9 & 45 \\
\hline 2 & Diplc & & 3 & 15 \\
\hline 3 & $\begin{array}{r}\text { Sarj } \\
\text { (S }\end{array}$ & & 7 & 35 \\
\hline 4 & $\begin{array}{r}\text { Pas } \\
\text { Sarj } \\
\text { (S }\end{array}$ & & 1 & 5 \\
\hline & Tot & & 20 & 100 \\
\hline
\end{tabular}

Sumber: data diolah

Pendidikan diartikan sebagai pendidikan formal yang dicapai atau diperoleh dibangku sekolah. Pendidikan formal yang ditempuh merupakan modal yang sangat penting karena dengan pendidikan seorang amilin mempunyai kemampuan dan dapat dengan mudah mengembangkan diri dalam bidang kerjanya.

Pendidikan pun dilakukan sebagai usaha untuk meningkatkan pengetahuan umum seorang amilin termasuk di dalamnya penguasaan teori untuk memutuskan persoalan-persoalan yang menyangkut kegiatan pencapaian tujuan lembaga. Dari pendidikan yang dimiliki amilin tersebut diharapkan mampu meningkatkan kinerja lembaga yakni mengarah kepada kualitas kerja, kuantitas kerja dan pemanfaatan waktu kerjanya. 
Banyaknya pekerjaan yang dilakukan dengan mutu hasil pekerjaan yang baik, sangat diharapkan oleh setiap lembaga, apalagi bila pekerjaan tersebut dilakukan dengan pemanfaatan waktuyang baik pula, tentunya hal ini akan menjadi nilai lebih tidak hanya bagi lembaga tetapi juga bagi amilin yang bekerja dalam lembaga tersebut.

Profil responden menurut jenjang pendidikan terakhir yang menunjukkan bahwa jenjang pendidikan responden terbesar adalah S1 yaitu sebesar $80 \%$ pada Lembaga Dompet Dhuafa dan pada BAZ Kota Bogor pendidikan terakhir SMA yang mendominasi yaitu sekitar $45 \%$. Hal ini dapat dikatakan bahwa amilin yang bekerja di Dompet Dhuafa rata-rata memiliki pendidikan sarjana (S1), selanjutnya dengan jenjang pendidikan amilin akan mempengaruhi kinerjanya, dimana semakin tinggi pendidikan amilin yang bekerja maka amilin akan semakin memiliki wawasan yang luas dalam penanganan pekerjaan.

Deskripsi profil responden menurut lamanya bekerja atau pengalaman kerja merupakan lamanya seseorang pegawai bekerja pada sebuah organisasi. Pengalaman kerja sangat penting dalam menjalankan usaha suatu lembaga. Dengan memperoleh pengalaman kerja, maka tugas yang dibebankan dapat dikerjakan dengan baik. Sedangkan pengalaman kerja jelas sangat mempengaruhi prestasi kerja karyawan karena dengan mempunyai pengalaman kerja, maka prestasi kerjapun akan meningkat. Pengalaman bekerja yang dimiliki seorang amilin, kadang - kadang lebih dihargai daripada tingkat pendidikan yang menjulang tinggi. Pepatah klasik mengatakan, pengalaman adalah guru yang paling baik (experience is the best of teacher). Pengalaman bekerja merupakan modal utama seseorang untuk terjun dalam bidang tertentu.

Dibawah ini dapat dilihat keadaan dari masing-masing lembaga yaitu Lembaga Amil Zakat Dompet Dhuafa dan
Badan Amil Zakat Kota Bogor menurut lamanya bekerja disajikan melalui tabel berikut ini:

\begin{tabular}{cccc} 
Tabel & 5. & $\begin{array}{c}\text { Karakteristik } \\
\text { Berdasarkan } \\
\text { Bekerja pada } \\
\text { Dhuafa }\end{array}$ & $\begin{array}{c}\text { Responden } \\
\text { Lamanya } \\
\text { Dompet }\end{array}$ \\
\hline No & $\begin{array}{c}\text { Lama } \\
\text { Bekerja }\end{array}$ & $\begin{array}{c}\text { Frekuensi } \\
\text { (Orang) }\end{array}$ & $\begin{array}{c}\text { Persentase } \\
(\%)\end{array}$ \\
\hline 1 & $\begin{array}{c}\text { Kurang } \\
\text { dari } 6\end{array}$ & 12 & 38,7 \\
& bulan \\
2 & $\begin{array}{c}\text { 6 bulan-1 } \\
\text { tahun }\end{array}$ & 9 & 29,03 \\
3 & $\begin{array}{c}1-5 \text { tahun } \\
6-10\end{array}$ & 6 & 19,36 \\
4 & tahun \\
5 & $\begin{array}{c}\text { Lebih dari } \\
10 \text { tahun } \\
\text { Total }\end{array}$ & 1 & 9,68 \\
\hline
\end{tabular}

Sumber: data diolah

Berdasarkan tabel berikut ini tentang deskripsi profil responden menurut lamanya bekerja yang menunjukkan bahwa lamanya bekerja responden rata-rata antara kurang dari 6 bulan.

Tabel 6. Karakteristik Responden Berdasarkan Lamanya Bekerja pada BAZ Kota Bogor

\begin{tabular}{cccc}
\hline No & $\begin{array}{c}\text { Lama } \\
\text { Bekerja }\end{array}$ & $\begin{array}{c}\text { Frekuensi } \\
\text { (Orang) }\end{array}$ & $\begin{array}{c}\text { Persentase } \\
(\%)\end{array}$ \\
\hline 1 & $\begin{array}{c}\text { Kurang } \\
\text { dari } 6\end{array}$ & 0 & 0 \\
bulan & & \\
2 & $\begin{array}{c}\text { 6 bulan-1 } \\
\text { tahun }\end{array}$ & 6 & 30 \\
3 & $\begin{array}{c}1-5 \text { tahun } \\
6-10\end{array}$ & 10 & 50 \\
4 & $\begin{array}{c}\text { tahun } \\
\text { Lebih dari } \\
10 \text { tahun } \\
\text { total }\end{array}$ & 0 & 20 \\
& 20 & 0 \\
& & 100 \\
\hline
\end{tabular}

Sumber: data diolah

Profil responden menurut lamanya bekerja ternyata lamanya bekerja responden yang terbesar adalah antara kurang dari 6 bulan yaitu sebesar 40. Hal ini dapatlah dikatakan bahwa amilin yang bekerja di Dompet Dhuafa rata-rata bekerja 
antara kurang dari 6 bulan, dimana semakin tinggi masa kerja karyawan maka akan semakin tinggi pula pengalaman karyawan dalam menangani setiap pekerjaan, sehingga dengan tingkat pengalaman amilin dalam menangani setiap pekerjaan maka akan semakin tinggi pula kinerja amilin yang dihasilkan oleh amil. Sedangkan pada BAZ Kota Bogor Masa Kerja yang lebih dominan yaitu antara masa 1-5 tahun.

Karakter responden menurut tingkat pendapatan adalah menguraikan atau menggambarkan responden menurut tingkat pendapatan yang diperoleh oleh responden itu sendiri. Oleh karena itulah akan disajikan karakter responden berdasarkan tingkat pendapatan yang dapat dilihat melalui tabel berikut ini:

Tabel 7. Karakteristik Responden Berdasar Tingkat Pendapatan pada Dompet Dhuafa

\begin{tabular}{|c|c|c|c|}
\hline No & $\begin{array}{c}\text { Tingkat } \\
\text { Pendapatan }\end{array}$ & $\begin{array}{c}\text { Frekuensi } \\
\text { (Orang) }\end{array}$ & $\begin{array}{c}\text { Persentase } \\
(\%)\end{array}$ \\
\hline 1 & $\begin{array}{l}\text { Kurang dari Rp. } \\
1.000 .000\end{array}$ & 0 & 0 \\
\hline 2 & $\begin{array}{l}\text { Lebih dari } \\
\text { Rp.1.000.000 } \\
\text { dan kurang dari } \\
\text { Rp. } 2.000 .000\end{array}$ & 0 & 0 \\
\hline 3 & $\begin{array}{l}\text { Lebih dari } \\
\text { Rp.2.000.000 } \\
\text { dan kuran dari } \\
\text { Rp. } 3.000 .000\end{array}$ & 28 & 90,32 \\
\hline 4 & $\begin{array}{l}\text { Lebih dari } \\
3.000 .000 \text { dan } \\
\text { kurang dari Rp. } \\
4.000 .000\end{array}$ & 3 & 9,68 \\
\hline 5 & $\begin{array}{l}\text { Lebih dari Rp. } \\
4.000 .000 \text { dan } \\
\text { kurang dari Rp. } \\
5.000 .000\end{array}$ & 0 & 0 \\
\hline 6 & $\begin{array}{l}\text { Lebih dari Rp. } \\
5.000 .000\end{array}$ & 0 & 0 \\
\hline & Total & 31 & 100 \\
\hline
\end{tabular}

Sumber: data diolah

Tabel di bawah ini menguraikan deskripsi profil responden menurut tingkat pendapatannya.

Tabel 8. Karakteristik Responden Berdasar Tingkat
Pendapatan pada BAZ

Kota Bogor

\begin{tabular}{|c|c|c|c|}
\hline No & $\begin{array}{c}\text { Tingkat } \\
\text { Pendapatan } \\
\end{array}$ & $\begin{array}{c}\text { Frekuensi } \\
\text { (Orang) }\end{array}$ & $\begin{array}{c}\text { Persentase } \\
(\%)\end{array}$ \\
\hline 1 & $\begin{array}{l}\text { Kurang dari Rp. } \\
1.000 .000\end{array}$ & 3 & 15 \\
\hline 2 & $\begin{array}{l}\text { Lebih dari } \\
\text { Rp.1.000.000 } \\
\text { dan kurang dari } \\
\text { Rp. } 2.000 .000\end{array}$ & 9 & 45 \\
\hline 3 & $\begin{array}{l}\text { Lebih dari } \\
\text { Rp.2.000.000 } \\
\text { dan kuran dari } \\
\text { Rp. } 3.000 .000\end{array}$ & 8 & 40 \\
\hline 4 & $\begin{array}{l}\text { Lebih dari } \\
3.000 .000 \text { dan } \\
\text { kurang dari Rp. } \\
4.000 .000\end{array}$ & 0 & 0 \\
\hline 5 & $\begin{array}{l}\text { Lebih dari Rp. } \\
4.000 .000 \text { dan } \\
\text { kurang dari Rp. } \\
5.000 .000\end{array}$ & 0 & 0 \\
\hline 6 & $\begin{array}{l}\text { Lebih dari Rp. } \\
5.000 .000\end{array}$ & 0 & 0 \\
\hline & Total & 20 & 100 \\
\hline
\end{tabular}

Sumber: data diolah

Banyaknya target dalam suatu lembaga menuntut perlu ditingkatkannya kinerja setiap karyawannya. Untuk mendorong peningkatan kinerja amilin dalam melaksanakan tugas dan kewajibannya, lembaga perlu memberikan insentif yang adil dan layak kepada setiap karyawan. Berdasarkan gambar tersebut di atas ternyata pendapatan responden yang terbanyak adalah lebih dari Rp 2.000.000 dan kurang dari Rp 3.000.000 dan untuk responden yang berada di BAZ Kota Bogor pendapatan yang mendominasi disana yaitu pada angka $\mathrm{Rp}$ Lebih dari $\mathrm{Rp}$ 1.000.000 dan kurang dari Rp 2.000.000. Pada umumnya karyawan yang puas dengan apa yang diperolehnya dari perusahaan akan memberikan lebih dari apa yang diharapkan dan ia akan terus berusaha memperbaiki kinerjanya.

\section{Analisis Persepsi Responden Mengenai Proses Rekruitmen dan Seleksi}

Salah satu upaya yang dilakukan oleh setiap lembaga dalam pencapaian tujuannya adalah pemberdayaan sumber daya insani yang berkualitas. Dimana dengan pemberdayaan SDI yang 
berkualitas maka akan berdampak dengan kinerja kerja yang dihasilkan. Oleh karena itulah guna menunjang pemberdayaan sumber daya insani yang berkualitas maka perlunya setiap lembaga memperhatikan masalah rekruitmen dan seleksi.

Masalah rekruitmen adalah salah satu upaya yang dilakukan dalam memperoleh SDI yang berkualitas, sebab kesalahan dalam merekrut amilin akan berakibat pada perkembangan lembaga yang tidak sesuai dengan apa yang diharapkan, begitupula dengan proses seleksi amilin. Oleh karena itulah maka perlunya lembaga menerapkan rekruitmen dan seleksi amilin yang ketat.

Hasil wawancara dan hasil olah data maka dapat disimpulkan bahwa rekruitmen yang dilakukan pada BAZ Kota Bogor dan Dompet Dhuafa berbeda karena pada BAZ kota Bogor tidak menggunakan iklan atau bahkan media lainnya dalam mendapatkan sumber daya insani yang dalam hal ini disebut sebagai amilin. BAZ Kota Bogor menggunakan sistem tertutup atau kedekatan untuk mendapatkan amilin, hal ini sesuai dengan tanggapan para amilinnya yang sebanyak $95 \%$ yang memilih proses pengangkatan. Sedangkan pada LAZ Dompet Dhuafa menggunakan media sebagai sarana unntuk menjaring sumber daya insani. Jawaban para responden ini sesuai dengan apa yang diberlakukan pada lembaga sehingga hasilnya sekitar $100 \%$ seragam, sehingga dapat langsung disimpulkan.

Setelah dilakukan penilaian mengenai persepsi jawaban responden mengenai rekruitmen maka akan dilakukan pembahasan mengenai persepsi jawaban responden mengenai pelaksanaan seleksi amilin. Salah satu tujuan yang dilakukan melalui seleksi amilin adalah untuk menyeleksi calon amilin yang akan bergabung dengan lembaga.

Dalam hubungannya dengan uraian tersebut di atas maka perlu dilakukan tanggapan responden mengenai pelaksanaan seleksi amilin khususnya pada BAZ Kota Bogor dan LAZ Dompet Dhuafa, hal ini dilakukan adalah untuk menganalisis pelaksanaan seleksi amilin yang telah dilakukan oleh BAZ Kota Bogor dan LAZ Dompet Dhuafa. Dalam penilaian mengenai seleksi ini ada beberapa indikator yang dipakai untuk menyeleksi yaitu mengenai nilai spiritual, emosional, intelektual, dan fisik seorang amilin.

Analisis persepsi mengenai nilainilai spiritual adalah suatu analisis untuk menguraikan atau menggambarkan jawaban responden mengenai kadar keimanannya. Oleh karena itulah setiap lembaga dalam melakukan pemberdayaan amil perlu melakukan peningkatan keimanannya kepada Allah SWT.

Memperlakukan karyawan dengan adil para amilin untuk sebuah kepentingannya lebih banyak memilih sangat penting sekali yang mencapai 75\%. Dan dalam kenyataannya diantara mereka lebih banyak memilih penting saja yaitu dengan persentase sebesar 65\%. Dan hanya sekitar $15 \%$ yang menganggap sangat penting sekali. Terdapatnya perbedaan dari perihal sebuah kepentingan dan kenyataan tersebut membuktikan bahwa dalam praktiknya mungkin masih terdapat beberapa hal yang menghalangi tindakan mereka untuk menyempurnakan kehidupan spiritual mereka, oleh karenanya perlu diadakannya suatu program dari lembaga yang dapat menambah keimanan.

Mengenai pengetahuan tentang teknik pengumpulan yang efektif amilin yang berada pada BAZ Kota Bogor dalam sebuah kepentingannya sekitar $75 \%$ memilih sangat penting sekali dan dalam kenyataannya hanya sekitar 15\% saja yang masih menganggap sangat penting sekali. Dalam pengetahuan mengenai pola pendistribusian dana produktif dalam sebuah kepentingannya amilin BAZ Kota Bogor banyak yang memilih sangat penting sekali dengan persentase sebesar 70\%, dalam kenyataannya hanya $10 \%$ saja yang masih memilih sangat penting sekali sedang sisanya sebesar 40 menganggap penting sekali. Untuk pengetahuan tentang 
golongan yang berhak menerima dana zakat dalam sebuah kepentingannya sebanyak $75 \%$ dari amilin di BAZ memilih sangat penting sekali, sedang dalam sebuah kenyataannya hanya sebesar $50 \%$ saja yang masih menganggapnya sebagai hal yang sangat penting sekali untuk diketahui. Sebagian besar amilin yang berada di BAZ sudah memiliki pengetahuan yang cukup untuk dapat menjalankan tugasnya sebagai seorang amilin.

Analisis persepsi mengenai nilainilai emosional adalah suatu analisis untuk menguraikan atau menggambarkan jawaban responden mengenai kondisi perasaan mereka.

Dalam hal keramahan untuk sebuah kepentingannya sebanyak $85 \%$ mengatakan sangat penting sekali sedangkan dalam kenyataannya 30\% saja yang masih menganggap hal tersebut sangat penting sekali, 50\% mengatakan sangat penting dan sisanya merasa cukup penting untuk sebuah keramahan.

Selanjutnya kepentingan seorang amilin berpikiran positif sebanyak 85\% mengatakan sangat penting sekali, dan untuk kenyataannya sebanyak 35\% mengatakan sangat penting sekali, 35\% sangat penting dan sisanya sebanyak 30 mengatakan cukup penting untuk berpikiran positif. Dan yang terakhir untuk sifat menghadapi segala kemungkinan sebanyak $75 \%$ mengatakan sangat penting sekali, dalam kenyataannya hanya $25 \%$ saja yang masih menganggap sangat penting sekali, 30\% merasa sangat penting saja dan sisanya sebanyak $45 \%$ menganggapnya cukup penting.

Untuk rasa empati, amilin LAZ DD dalam sebuah kepentingannya lebih banyak memilih sangat penting sekali dengan persentase sebesar $68 \%$, dan untuk kenyataannya hanya sebesar $55 \%$ saja yang memilih sangat penting sekali, kemudian 29\% memilih sangat penting dan sisanya sebesar $16 \%$ lebih memilih penting saja. Selanjutnya untuk rasa tanggung jawab sebesar 71\% amilin DD memilih sangat penting sekali yang dalam kenyataannya hanya sebesar $42 \%$ yang masih tetap memilih sangat penting sekali, jumlah persentase ini sama dengan jumlah persentase amilin yang memilih sangat penting, sedang sisanya sebesar $7 \%$ untuk penting dan $10 \%$ lagi untuk cukup penting.

Dalam menepati janjinya amilin DD lebih banyak memilih sangat penting sekali dengan jumlah $84 \%$ dan dalam sebuah kenyataannya sebesar $20 \%$ saja yang masih memilih sangat penting sekali, dan persentase yang paling besar jatuh pada pilihan sangat penting yaitu sebesar $42 \%$, dan sisanya 39\% lebih memilih penting. Untuk keramahan dengan nilai kepentingannya sebesar 84\% memilih sangat penting sekali, dan dalam kenyataannya hanya 39\% yang memilih sangat penting sekali, sisanya sebesar $58 \%$ memilih sangat penting, $3 \%$ cukup penting dan 3\% pula untuk penting saja.

Selanjutnya dalam memiliki pikiran yang positif amilin yang berada di DD lebih banyak memilih sangat penting sekali dengan jumlah persentase sebesar 84\%, dan untuk sebuah kenyataannya sekitar 29\% yang masih dalam pilihannya yaitu sangat penting sekali, sedang yang lainnya lebih memilih sangat penting saja dengan jumlah persentase sebesar 45\% dan sisanya 23\% memilih cukup penting dan $3 \%$ lainnya lebih memilih penting. Dan yang terakhir untuk sebuah kesiapannya dalam menghadapi segala kemungkinan yang akan para amilin yann berada di DD lebih banyak memilih sangat penting sekali sebanyak 65\%. Dan untuk kenyataannya sebesar $20 \%$ yang memilih sangat penting sekali, 55\% nya lebih memilih sangat penting dan cukup penting sebesar 23\% dan sisanya sebesar 3\% memilih penting saja.

Analisis mengenai kondisi fisik ini merupakan suatu analisis yang menguraikan atau menggambarkan jawaban responden mengenai kebiasaannya yang akan mencerminkan kondisi kesehatannya seorang amilin kedepannya. 
Untuk sebuah kerapihan dalam penampilan amilin BAZ Kota Bogor sekitar $70 \%$ memilih sangat penting sekali dalam kepentingannya, dan hanya 20\% yang masih memilih sangat penting sekali menjaga kerapihan dalam kenyataannya, 40\% memilih sangat penting, 30\% cukup penting, dan sisanya sebesar $10 \%$ memilih penting untuk menjaga kerapihan dalam berpenampilan. Terakhir untuk gaya berpakaian yang selalu mengikuti zaman dalam sebuah kepentingannya amilin BAZ Kota Bogor lebih banyak memilih sangat penting sekali sebanyak 45\%, dan $10 \%$ menganggap tidak penting untuk berpakaian mengikuti zaman dan sisanya memilih cukup penting sebesar 5\%, dan $25 \%$ menganggap sangat penting untuk bergaya mengikuti zaman, sedangkan untuk kepentingannya hanya sebesar 10\% yang menganggap sangat penting sekali dan 5\% nya menganggap tidak penting, sedangkan sisanya $25 \%$ memilih cukup penting, 45\% menganggap cukup penting dan $15 \%$ lainnya menganggap sangat penting.

Kemudian dalam penampilan, amilin LAZ DD banyak yang menganggap bahwa berpenampilan menarik itu sangat penting sekali dalam segi kepentingannya, dan berbeda dengan apa yang terjadi pada kenyataannya yang hanya sekitar 29\% yang masih menganggap bahwa penampilan itu sangat penting sekali, sisanya 29\% merasa sangat penting dan yang lainnya sebanyak 39\% merasa cukup penting berpenampilan rapi. Dan yang terakhir yaitu gaya penampilan yang mengikuti zaman, amilin DD sebanyak 39\% mengatakan bahwa sangat penting sekali untuk berpakaian mengikuti zaman dalam sebuah kepentingannya, sedang dalam kenyataannya hanya sebanyak $10 \%$ yang masih menganggap bahwa berpakaian sesuai dengan zaman itu sangat penting sekali, dan sisanya sebesar 23\% merasa sangat penting, 58\% cukup penting, 3\% penting dan $7 \%$ mengatakan tidak penting untuk berpakaian mengikuti zaman.
Analisis persepsi mengenai kinerja ini yaitu suatu analisis untuk menguraikan atau menggambarkan jawaban responden mengenai apa yang telah mereka kerjakan.

Dalam mengerjakan pekerjaan sesuai dengan perintah atasan amilin yang berada di BAZ sebagian besar dari mereka menilai dalam sebuah kepentingannya yaitu sangat penting sekali mengerjakan pekerjaan sesuai dengan perintah atasan yaitu sebanyak 75\%, dan untuk kenyataannya hanya sekitar $10 \%$ saja yang masih menilai sangat penting sekali. Selanjutnya untuk kepandaian dalam berbicara amilin yang berada di BAZ Kota Bogor sebesar 75\% memilih sangat penting sekali untuk melakukan pekerjaan sesuai dengan perintah untuk sebuah kepentinggannya akan tetapi dalam kenyataannya hanya sekitar 35\% saja yang masih bertahan memilih sangat penting sekali.

Kepandaian dalam mencari jalan keluar sebagian dari amilin yang berada pada BAZ Kota Bogor sebagian besar menilai sangat penting sekali untuk dapat melakukan hal tersebut dengan perolehan persentase sebanyak 75\%, dan untuk sebuah kepentingnnya hanya sekitar 15\% saja yang masih mempertahannya dengan sangat penting sekali dan sisanya sekitar $60 \%$ memilih sangat penting, 20\% lainnya memilih cukup penting dan sisanya sebesar 5\% lebih memilih penting untuk memiliki kepandaian dalam mencari jalan keluar.

Selanjutnya dalam perolehan pendapatan yang sesuai dengan kinerja dalam kepentingannya amilin BAZ Kota Bogor banyak yang memilih sangat penting sekali sebanyak $70 \%$ dan untuk kenyatannya banyak diantara mereka yang memilih cukup penting sebanyak 50\%, hal ini terjadi mungkin Karen diantara mereka masih ada yang kurang puas dengan apa yang telah mereka peroleh sehingga sebagian besar hanya memilih cukup penting saja. Dan yang terakhir yaitu dalam hal hukuman yang diberikan oleh lembaga bagi mereka yang melanggar, untuk kepentingannya banyak diantara mereka 
yang memilih sangat penting sekali yaitu sebanyak $75 \%$ sedangkan dalam kenyataannya hanya $15 \%$ saja yang masih tetap memilih sangat penting.

Kemudian dalam hal pengerjaan pekerjaan sesuai dengan yang diperintahkan amilin DD untuk kepentingannya sebanyak $81 \%$ memilih sangat penting sekali, dan untuk kenyataannya hanya sebesar $23 \%$ saja yang masih memilih sangat penting sekali sedang yang lainnya lebih condong memilih sangat penting saja. Selanjutnya untuk kepandaian dalam berbicara amilin DD sebanyak 58\% memilih sangat penting sekali dan sisanya memilih sangat penting saja untuk sebuah kepentingannya, dan untuk kenyataannya 29\% lebih memilih sangat penting sekali bahkan ada yang menganggap bahwa kepandaian dalam berbicara itu tidak penting sebanyak 3\%.

Kepandaian dalam mencari solusi ketika dalam masalah amilin DD sebanyak $61 \%$ memilih sangat penting sekali dan sisanya $39 \%$ memilih sangat penting saja untuk kepentingannya sedang dalam kenyataannya hanya sebesar $16 \%$ saja yang memilih sangat penting sekali, dan mayoritas dari mereka meilih sangat penting saja untuk memiliki kepandaian dalam hal mencari solusi yitu sebesar $45 \%$, dan sisanya memilih cukup penting $26 \%$ dan penting sebesar 13\%. Dalam hal perolehan pendapatan $77 \%$ beranggapan sangat penting sekali untuk mendapatkan pendapatan sesuai dengan kinerja, namun dalam kenyataannya hanya sebesar $16 \%$ saja yang masih merasa bahwa pendapatan yang didapat itu sangat penting sekali karena merasa telah sesuai dengan pendapatannya yang diperolehberdasarkan kinerjanya selama ini, sedang yang lainnya yaitu sekitar $54 \%$ hanya merasa sangat penting untuk mendapat pendapatan yang sesuai dengan kinerjanya dan 23\% lainnya merasa cukup penting dan sisanya sekitar 7\% memilih penting untuk memperoleh pendapatan yang sesuai dengan kinerjanya, hal ini terjadi karena mungkin mereka tidak merasa puas dangan apa yang telah mereka peroleh dengan apa yang telah mereka kerjakan.

Untuk pernyataan terakhir yaitu mengenai hukuman yang diterapkan oleh lembaga terhadap para karyawan yang melanggar. Amilin yang berada pada LAZ DD pada tingkat kepentingannya lebih banyak yang memilih sangat penting sekali untuk menerapkan hukuman bagi mereka yang melanggar deng perolehan skor sebanyak $81 \%$, namun pada kenyataannya hanya sekitar $26 \%$ saja yang masih memilih sangat penting sekali untuk menerapkan itu. Pada kenyataannya Amilin DD lebih banyak yang memilih sangat penting saja untuk hukuman bagi yang melanggar, bahkan ada sebanyak 3\% yang memilih tidak penting untuk hukuman tersebut, hal ini terjadi mungkin karena merasa hukuman tersebut tidak berjalan sehingga mereka memilih pilihan tersebut.

\section{Uji Validitas dan Reliabilitas}

Nilai korelasi dari setiap instrumen penelitian yakni 0,372-0,795. Selain itu masing-masing berkorelasi signifikan sebab memiliki nilai sig $<0,05$, karena nilai korelasi diatas dari 0,30 dan selain itu kurang dari 0,05 berarti semua item pertanyaan dapat dikategorikan valid.

Uji reliabilitas digunakan untuk mengetahui konsistensi alat ukur, apakah alat ukur yang digunakan dapat diandalkan dan tetap konsisten jika pengukuran tersebut diulang. Sekarang dalam Dwi (2009, hal. 98) bahwa reliabilitas kurang dari 0,60 kurang baik, sedangkan 0,70 dapat diterima dan 0,80 adalah baik. Oleh karena itulah akan disajikan hasil uji reliabilitas yang dapat dilihat pada tabel berikut ini:

Tabel 9. Ringkasan Uji Reliabilitas Cronbach's

\begin{tabular}{cc} 
Alpha & N of Items \\
\hline .933 & 28 \\
\hline
\end{tabular}

Sumber: Data diolah dengan SPSS 16

Tabel di atas membuktikan bahwa hasil uji reliabilitas memiliki cronbach's 
alpha 0,933 . Hal ini dapat dikatakan bahwa item pertanyaan yang akan digunakan semua item pertanyaan dapat dikategorikan andal/reliabel sebab memiliki cronbach's alpha di atas dari 0,60. Dengan demikian dapat dikatakan bahwa semua item pertanyaan yang telah diolah memiliki tingkat keandalan yang tinggi dalam proses pengujian hipotesis.

\section{Analisis Sistem Rekruitmen dan Seleksi Pada Lembaga Zakat}

Dalam pengadaan tenaga kerja amilin Dompet Dhuafa menyerahkan sepenuhnya kepada bagian Human Research dengan teknis seperti yang digambarkan pada gambar berikut ini:

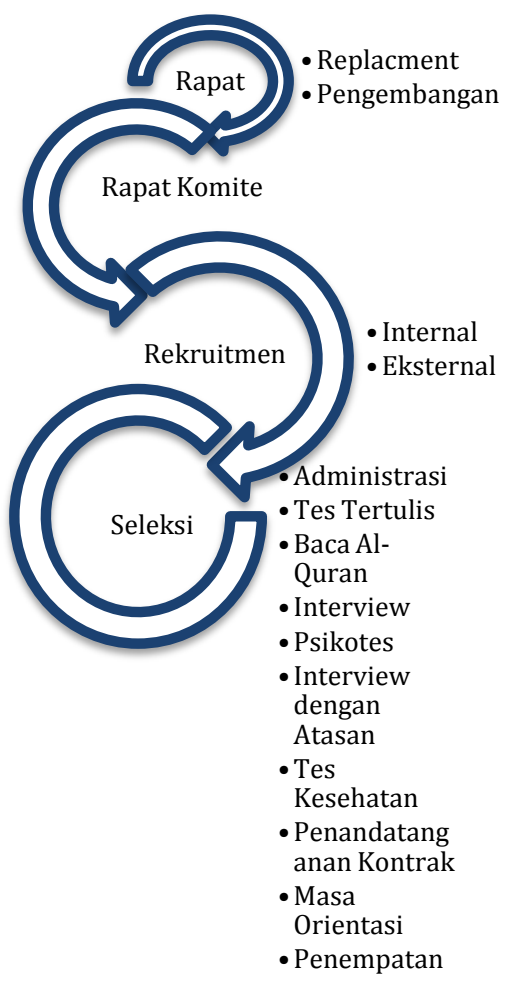

Gambar 2

Mekanisme Rekruitmen dan seleksi di Dompet Duafa

Mekanisme perekrutan dan seleksi amilin pada masing-masing lembaga zakat yang akan berpengaruh terhadap kualitas amilin perlu diperbaiki agar kinerja yang dihasilkan dapat memenuhi harapan lembaga sehingga akan meningkatkan jumlah pemasukan dana zakat yang dikumpulkan. Peningkatan kualitas ini dapat dilakukan dengan cara mencari tahu terlebih dahulu masalah yang terdapat pada mekanisme perekrutan dan seleksi yang membuat sistem tidak berfungsi sebagai mana mestinya. Masalah-masalah tersebut diketahui maka untuk memverifikasi penyebab-penyebab dari masalah-masalah yang dihadapi dapat dilakukan dengan diagram fishbone atau lebih sering dikenal dengan diagram ikan.

Pada Badan Amil Zakat kota Bogor masalah yang timbul yaitu karena sistem rekruitmen yang diadopsi yaitu berdasarkan rekomendasi dan berdasarkan surat lamaran yang masuk tanpa adanya pemberitahuan atau open rekruitmen, sehingga pelamar atau calon amil yang terjaring terbatas. Dalam sistem seleksi BAZ Kota Bogor lebih banyak mengangkat amil dengan berdasarkan kepercayaan karena kebanyakan dari mereka yang menjadi calon amil telah dikenal sebelumnya.

Lembaga Dompet Dhuafa telah memanfaatkan segala media yang ada seperti media elektronik dan cetak untuk menyebarkan pemberitahuan pembukaan lowongannya. Akibatnya banyak sekali para pelamar yang terjaring, berkat kemudahan yang didapatkan dari penggunaan media sehingga banyak para pelamar yang hanya sekedar coba-coba melamar tanpa memiliki minat bekerja di lembaga. Hal ini membuat sistem seleksi harus lebih ketat agar semua yang lolos dalam seleksi itu adalah benar-benar calon amil yang berkualitas, sehingga dana yang dikeluarkan untuk kegiatan rekruitmen dan seleksi ini tidak terbuang dengan percuma.

Setelah mengetahui masalah yang ada maka penelitian ini dilanjutkan dengan meningkatkan kualitas amilin dengan pendekatan terhadap mekanisme rekruitmen dan seleksi pada lembaga.variabel rekruitmen dan seleksi yang perlu diprioritaskan adalah variabel yang memiliki tingkat kepentingan yang 
tinggi namun memiliki tingkat kinerja yang rendah.

Metode Importance Performance Analysis (IPA) digunakan dalam penelitian ini untuk menentukan tingkat kinerja amil. Dengan memakai metode ini dimaksudkan dapat mengetahui masing-masing keadaan variabel dari faktor-faktor rekruitmen dan seleksi ditinjau dari segi kepentingan dan kinerja masing-masing variabel. Posisi penempatan masing-masing variabel menurut persepsi responden yang dalam hal ini merupakan para amil yang bekerja pada lembaga Dompet Dhuafa dan BAZ Kota Bogor. Hasilnya dapat dilihat pada diagram kartesius yang terbagi atas empat kuadran. Penentuan dari letak variabel didapatkan dari rata-rata tingkat kepentingan dan rata-rata tingkat kenerja atau kenyataan dari keadaan yang mereka alami sendiri.

Perolehan nilai rata-rata variabel rekruitmen dan seleksi diatas berdasarkan tingkat Importance dan performance yaitu kepentingan (Importance) yaitu sebesar 4,68 dan tingkat performanceadalah sebesar 3,75. Untuk lebih jelasnya tabel diatas akan disajikan dengan menggunakan gambar atau diagram, seperti pada grafik dibawah ini:

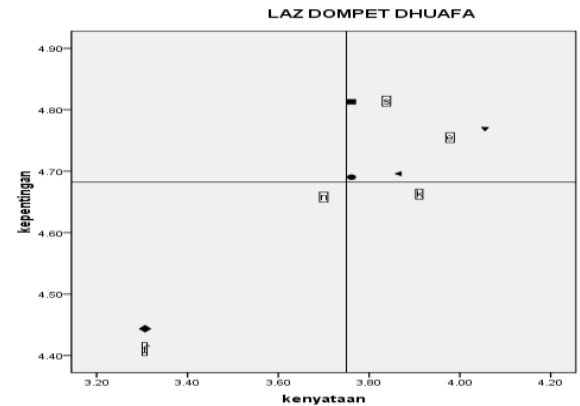

Sumber: data diolah

Gambar 3.

diagram kartesius Importance dan performance Analisis Sistem Rekruitmen dan Seleksi di Dompet Dhuafa

Variabel yang terdapat pada kuadran 1 adalah variabel yang memiliki prioritas utama dalam perbaikan. Pada gambar grafik diatas telihat bahwa tidak ada variabel sistem rekruitmen dan seleksi yang berada pada wilayah ini. Sehingga dapat dikatakan bahwa sistem rekruitmen dan seleksi yang digunakan oleh Dompet
Dhuafa telah sesuai dengan kebutuhan yang ada.

Variabel-variabel yang terletak pada kuadran II adalah variabel yang menurut amil itu sendiri telah memenuhi harapan yang mereka inginkan sehingga dirasa baik. Variabel yang berada pada kuadran ini harus dipertahankan oleh lembaga dan amil itu sendiri, variabel-variabel itu adalah nilai spiritual, intelektualitas, emosional, dan kinerjanya.

Atribut yang terletak pada kuadran III ini dianggap memiliki tingkat kepentingan yang rendah oleh amilin sehingga perbaikannya menjadi prioritas rendah dan kenyataannya variabel pada kuadran III ini kinerjanya rendah. Variabel yang berada pada kuadran ini yaitu kondisi fisik, hal ini dirasa tidak begitu penting sehingga terabaikan.

Variabel yang terdapat pada kuadran IV berarti menunjukkan tingkat kepentingan dan dari variabel tersebut dinilai rendah oleh amilin yang berada di Dompet Dhuafa, akan tetapi kinerja atribut ini dianggap tinggi oleh amilin Dhompet Dhuafa. dan seperti yang terlihat pada diagram diatas bahwa tidak ada satu pun variabel yang terdapat pada kuadran tersebut.

Untuk perolehan nilai rata-rata variabel pada BAZ Kota Bogor yaitu berdasar tingkat kepentingan sebesar 4,56 dan kinerja sebesar 3,62 nilai ini sama besarnya dengan jumlah rata-rata yang diperoleh dari Dompet Dhuafa. Untuk posisi variabel-variabel hasil dari responden yang berasal dari BAZ Kota Bogor adalah sebagai berikut:

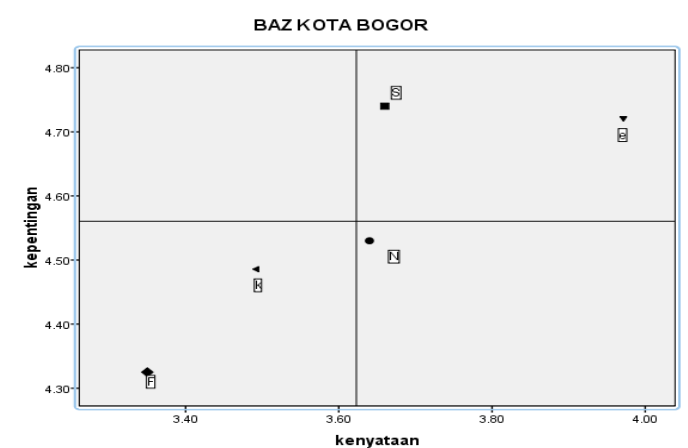

Sumber: data diolah 


\section{Gambar 4}

diagram kartesius Importancedan

Performance Analisis Sistem Rekruitmen dan Seleksi di BAZ Kota Bogor

Seperti yang dijelaskan di atas, bahwa variabel-variabel yang berada pada kuadran I merupakan variabel yang harus menjadi prioritas utama dalam perbaikannya. Pada Badan Amil Zakat hal atau variabel yang menjadi prioritas utama tidak jauh berbeda dengan yang dialami oleh para responden amil di Dompet Dhuafa, pada BAZ pun tidak ada satu variabel pun yang terdapat pada kuadran ini.

Variabel yang berada pada kuadran II ini harus dipertahankan, karena menurut responden atribut atau variabel yang rekruitmen dan seleksi yang telah ada sudah sesuai dengan harapan yang diinginkan. Variabel yang masuk kepada kuadran II ini yaitu variabel spiritual dan emosional.

Variabel yang terletak pada kuadran III ini dianggap memiliki tingkat kepentingan yang rendah sehingga perbaikannya menjadi prioritas yang rendah. Pada kenyataannya variabel ini memiliki kinerja yang rendah. Dan variabel yang termasuk pada kuadran ini adalah fisik dan kinerjanya.

Tingkat kepentingan terhadap kuadran IV ini dinilai rendah oleh amilin akan tetapi tingkat kinerjanya dianggap tinggi. Variabel pada kuadran ini dinilai memiliki tingkat kepentingan rendah, hal ini dapat dikaitkan dengan tingkat pendidikan responden yang tinggi, sehingga cenderung memiliki prioritas terhadap tingkat kepentingan dan kesadaran variabel-variabel lainnya yang menunjang tugas sebagai seorang amilin. Variabel tersebut yaitu terdapat pada nilai intelektualitasnya.

\section{KESIMPULAN DAN IMPLIKASI}

Berdasarkan hasil penelitian analisis mengenai sistem rekruitmen dan seleksi amilin yang diterapakan oleh lembaga pengelola zakat (studi kasus Dompet Dhuafa dan Badan Amil Zakat Kota Bogor), maka dapat ditarik kesimpulan sebagai berikut:

1. Karakteristik responden yang ada pada kedua lembaga zakat ini didominasi oleh responden yang berpendidikan SMA pada BAZ Kota Bogor dan S1 pada LAZ Dompet Dhuafa. Sebagian besar amilin yang berada di BAZ Kota Bogor telah mengabdi selama kurang lebih 15 tahun sedangkan untuk LAZ DD ratarata dari mereka telah bekerja kurang lebih selama 6 bulan-1 tahun dan pendapatan yang diperoleh oleh amil yang berada di BAZ yaitu kurang lebih sebanyak Rp 1000.000-2000.000 sedangkan pendapatan yang diterima oleh para amil di DD yaitu kurang lebih sebanyak Rp 2000-000-3.000.000

2. Hasil yang didapat dari penelitian dengan menggunakan metode IPA adalah untuk BAZ Kota Bogor variabel spiritual dan emosional merupakan variabel yang harus dipertahankan untuk dapat terus mempertahankan kinerja yang telah dicapai, dan untuk LAZ Dompet Dhuafa variabel yang harus dipertahankannya yaitu variabel spiritual, emosional, intelektual, dan kinerjanya.

Implikasi yang dapat dijadikan masukan bagi Lembaga Pengelola Zakat Dompet Dhuafa dan Badan Amil Zakat Kota Bogor adalah pemilihan calon amilin tidak hanya melihat penampilan luarnya saja dan keahlian akan tetapi akhlaknya pun harus jadi prioritas utama dalam sistem perekrutan seleksi para amilin.

\section{DAFTAR PUSTAKA}

Abduh, Muhammad, 2009, Zakat: Tinjauan Fikih dan Teori Ekonomi Makro Modern, Jakarta: Fath Publishing

Ali, M.Daud, 1988, Sistem Ekonomi Islam, cetakan pertama, Jakarta: UI

Allan \& Barbara Pease, Islam menerangkan perbedaan antara wanita dan laki- 
laki,

2012 ,

http://jejakjejakjejak.wordpress.co

$\mathrm{m} / 2012 / 08 / 24 /$ seputar-

perbedaan-antara-wanita-dan-laki-

laki-dalam-perempuan/, selasa 10

september 2013.

Al-Ustadzah Ummu Ishaq Al-Atsariyyah, Hak-hak wanita dalam Islam,http://akhwat.web.id/muslim ah-salafiyah/muslimah/hak-hakwanita-dalam-islam/selasa 10

September 2013

Daradjat, Zakiah, 1994, Zakat: Pembersih Harta dan Jiwa, cetakan keenam, Bandung: CV. Ruhama

El-Bantanie, M. Syafi'ie, 2009, Zakat, Infak, dan Sedekah, cetakan I, Jakarta: Salamadani

Erwin Wahyu Irianti, Analisis Importance Performance Lingkungan Hunian Terhadap Persepsi Pembeli Pada Perumahan Riverside Malang

Hafiduddin, Didin, 2002, Zakat: Dalam Perekonomian Modern, Jakarta: Gema Insani

Hariandja, Marihot, T.E, 2009, Manajemen Sumber Daya Manusia: Pengadaan, Pengembangan, Pengkompensasian, dan Peningkatan Produktivitas Pegawai, cetakan kelima, Jakarta: Grasindo

Infoz, Media informasi Organisasi Pengelola Zakat, 2011, Sertifikasi Amil, Perlukah?, Edisi II Th VI Maret-April

Infoz, Media informasi Organisasi Pengelola Zakat, 2011, Pemerintah Kunci Pintu LAZNAS Baru?, Edisi 12 Th. VI MeiApril

Jusmaliani, 2011, Pengelolaan Sumber Daya Insani, cetakan pertama, Jakarta: PT. Bumi Aksara
Keunggulan Wanita Dibandingkan Pria http://arhamvhy.blogspot.com/201 2/06/10-kelebihan-wanitadibanding-pria.htmlselasa $\quad 10$ september 2013.

Muhammad Aji Nugroho, 2012, Pengaruh Proses Rekruitmen dan Seleksi Terhadap Kinerja Karyawan PT. Angkasa Pura I (Persero) Bandara Internasional Sultan Hasanuddin Makasar.

Mufraini, M.Arif, 2006, Akuntansi Dan Manajemen Zakat: Mengomunikasikan Kesadaran dan Membangun Jaringan, cetakan ke dua, Jakarta: Kencana

Nuryanta, Nanang, 2008, Pengelolaan Sumber Daya Manusia: Tinjauan Aspek Rekruitmen dan Seleksi, Jurnal Pendidikan Islam El- Tarbawi

Rivai, Viethzal, 2009, Islamic Human Capital: Dari Teori ke Praktik, Manajemen Sumber Daya Manusia, Jakarta: Grafindo

Sastrohadiwiryo, Dr. B. Siswanto.2005.Manajemen Tenaga Kerja Indonesia (Pendekatan Administrasi dan Operasional), PT. Bumi Aksara, Jakarta, cetakan ke 3 : Desember.

Sudewo, Eri, 2004, Manajemen Zakat; Tinggalkan 15 Tradisi Terapkan 4 Prinsip Dasar, cetakan pertama, Jakarta: Imz

Susilo, Willy, 2002, Audit Sumber Daya Manusa: Panduan Komprehensif Auditor dan Praktisi Manajemen Sumber Daya Manusia serta Pimpinan Organisasi/Perusahaan, Jakarta: Gema Amini. 
Syibli, M, Indung Sudarso dan Subakti Cipto Mulyono, "Analisis Pengaruh Faktorfaktor Rekruitmen terhadap Kinerja SDM Outsourcing PT Telkom dengan Pendekatan SEM (Structural Equation Modelling)"Pasca Sarjana Magister Manajemen Teknnologi ITS, Kampus ITS Surabaya

Utomo, Setiawan B., 2009, Metode Penerapan Nisab Zakat: Model Dinamis BerdasarkanStandar Nilai Emas dan Kebutuhan Hidup Layak (KHL) Provinsi, Bandung: Mizan Media Utama

Wirjayanitri, Anggraini, 2005, Peranan Baz Sebagai Pengelola Zakat dalam Upaya Mengubah Status Mustahik Menurut Undang-undang Nomor 38 th 1999, Skripsi pada Program Pasca Sarjana, Universitas Diponogoro, Semarang 